\title{
Financial Factors Affecting Earnings Management and Earnings Quality: New Evidence from an Emerging Market
}

\author{
Isam Saleh ${ }^{1, *}$, Malik Abu Afifa ${ }^{1}$, Fadi Haniah ${ }^{2}$ \\ ${ }^{1}$ Al Zaytoonah University of Jordan, College of Business, Department of Accounting \\ ${ }^{2}$ The World Islamic Sciences and Education University, Jordan
}

ARTICLE INFO

\section{Article history:}

Received 01 August 2020

Revised 23 August 2020 and 28

September 2020

Accepted 16 October 2020

Published 06 November 2020

\section{Keywords:}

Financial factors

Earnings manipulation

Reporting quality

Financial information quality

Jordanian market

JEL classification: M21, M41, G30

\begin{abstract}
The purpose of this study is to examine the effect of financial factors on earnings management and earnings quality. Moreover, the study examines the role of earnings management as a mediator in the effect of the financial factors on earnings quality. It provides some empirical evidences from an emerging market, especially from the Jordanian market. The study uses a panel data analysis method over a ten-year period (2009-2018). The study population includes all Jordanian insurance companies listed in Jordanian market at the end of the year 2019, and the study sample consists of 20 Jordanian insurance companies (a complete population), giving a total of 200 observations for each variable. The results indicate that all financial factors in the model combined affect the earnings management and earnings quality. In addition, earnings management negatively affects earnings quality, and earnings management fully mediates the effect of financial factors on earnings quality. The study advises that policy makers ought to follow good legislation to curb the company's earnings management activities. Hence, the policy makers need to apply regulations which enrich the company's effectiveness and efficiency whilst protecting the investors and other interested parties from risk.
\end{abstract}

\section{Introduction}

Both theoretical and empirical researches in accounting have core topics within which are earnings management and earnings quality. The idea of earnings management is to show progressive earnings quality that could live up to either the requirement of obtaining relevant authorisation from regulators, or the shareholders' expectation (Ahmadpour \& Shahsavari, 2016). Chang et al. (2016) mentioned that, in order to provide a channel for the managers of corporations, they would need a flexibility in reporting, which could negatively impact earnings quality and its utility in the decision-making process.

After several scandals in financial accounting, a dominant role is played by financial statements and accounting information in the decision-making process and in the evaluation of the performance, in addition to the financial positioning of corporations by conveying this data and information to potential and current investors and creditors to help them in making decisions. For example, Banco Epirito Santo in 2014, British Telecom in 2017 and Dick Smith in 2016. The rules in accounting, in addition to the policies and regulations, allow the managers and accountants to utilise their judgements and choose certain choices in their financial reports (Du \& Shen, 2018; Huynh, 2018). Hence, imposing an accrual system is important to show the pertinent and continuous information revolving around the financial operation because managers always have the chance to manipulate profits by altering the timing expense and revenue recognition (Almasarwah, 2019; Saleh \& Al-Sraheen, 2017). Then, accruals occur due to the aggressive actions of management against recognition, recording and reporting the financial events, which is an important tool for manipulating financial statements.

\footnotetext{
* Corresponding author.

E-Mail address: i.saleh@zuj.edu.jo
} 
Based on Leggett et al. (2016), Warrad (2017) and Huynh (2018), past research has tried to uncover the links between earnings quality. Because the accounting information manipulation inversely relates to the quality of earnings, it is suggested that it is reason of a company to have its reputation tarnished, which, in turn, would cause stagnant and exponential decrease in the future financial performance.

Hence, empirical studies have endorsed the earnings quality as one of the most authoritative factors in affecting the company's finances (Du \& Shen, 2018; Latif et al., 2017; Tabassum et al., 2014). It is argued that the higher the quality of earnings reported, the more public confidence and goodwill are gained, in order to gain competitive advantage and superior subsequent performance. On the other hand, a second line of research recommended that businesses and companies with weak financial results may have more pressure to distort their financial accounting to handle their earnings, leading to lower reported earnings quality (Warrad, 2017; Dechow et al., 2010).

Concerning earnings management and quality, all past studies showed that the aforementioned could face two associated difficult challenges in financial reporting, where earnings management is a trait affecting earnings quality (Mostafa, 2020; Mostafa \& Ibrahim, 2019). Managers make optional accounting choices that are deemed as either distorting disclosure or efficient communication of private information. However, manipulation of earnings purposely done by managers, within limits, is premised by the Accounting Standards. This may misrepresent the practicality of financial reporting to users. In this case, earnings management is portrayed as a practice that can lead to poorer quality of earnings if it pinpoints the results of management's opportunistic use of accruals with the justification of misleading users (Alsufy et al., 2020).

Jordanian market as an emerging market is characterized by a small proportion of quoted companies, weak investor protection, as well as a code law tradition (Abdullatif, 2016; Abdullatif \& Al-Khadash, 2010; Francis \& Wang, 2008). The ownership structure in Jordanian companies is concentrated, and the traditional family character prevails in members (Almarayeh et al., 2020). In the term of earnings management and earnings quality, financial bonding and personal relations in Jordanian business environment are widespread and affect the decisions selection (World Bank, 2004). For example, financial bonding and personal relations affect the auditor selection, and this is may reduce the transparency in doing audit tasks, hence the real earnings management practices will be higher (Shbeilat \& Abdel-Qader, 2018; Abdullatif \& Al-Khadash, 2010).

In addition, the concentrated ownership structure of Jordanian companies causes a low demand for high-quality external audits compared to contexts characterized by dispersed ownership (Almarayeh et al., 2020; Abdullatif \& AlKhadash, 2010), and thus the real earnings management practices in these companies will increase (Niskanen et al., 2011). Besides, the higher earnings management practices and lower earnings quality in Jordanian companies refer to the fact, the governance and controlling level in these companies under the low level, where prior studies (e.g. Chang \& Sun, 2009) argued that there are negative and positive relationships between governance practices with earnings management practices and earnings quality, respectively.

From the context, this study assists the global literature in several ways. To begin with, this study is the first of its kind to explore earnings management as the role of mediator in affecting financial factors on the quality of earnings. Particularly, empirical literature (e.g. Al-Mousawi \& Al-Thuneibat, 2011; Al-khabash \& Al-Thuneibat, 2008) conducted that Jordanian companies have indicated that most Jordanian companies have practiced their earnings management in their statements. As a consequence of such a practice this would decreasing the value of a company, its transactions and its reputation (Sraheen \& Saleh, 2017; Abbadi et al., 2016). The second way this paper helps the literature is by showing the explanatory power of earnings quality and management in developing markets. Finally, this paper may possibly be beneficial as a supporting major factor for regulatory action, specifically the actions that impact the decision-making of the managers. Hence, the outcomes contain significant inferences for supervisors and regulators. Comprehending how financial factors impact earnings management and increase the quality of financial reporting, will be very beneficial to them.

The rest of this study follows a certain structure, which goes as such. The next section is the literature review and hypotheses development. Section 3 shows the measurements of this study, which are the research model and selecting the samples. After that Section 4 debates the analysis of the regression and finally, the findings are summarised in Section 5 . 


\title{
Literature Review and Hypotheses Development
}

\author{
Underlying Theories
}

The conceptual framework of the current study is based on two underlying theories, namely agency theory and signalling theory. The next two sections provide some explanations about these theories that link with this study.

\section{Agency Theory}

The theory of the agency is defined as an arrangement between one or more of the parties, identified as a principal, which binds the other party, identified as an agent, with a view to transferring control of the interests of the company, which also involves the distribution of authority in the decision-making process to the agents (Jensen \& Meckling, 1976; Davidson et al., 2004). The main problem of agency theory is agency conflict. Agency conflict comes from the conflicting interests between the principals (the owners) and the agents (management). The principals are interested in maximising their profit, which is also the interest of the management (Okolie, 2014; Okolie et al., 2013). When it comes to information of earnings, the conflict of agency could lead to dysfunctional behaviour by management, such as earnings management. The separate interests of the principals (owners) and the agents (management) may become a source of dispute, as certain agents may not behave perfectly in the best interests of the principal. Incompatible desires can lead to inefficiencies and financial losses on the part of each stakeholder. This leads to the principal-agent problem.

In the field of earnings management under agency theory, empirical research (e.g., Jiraporn et al., 2008) have established agency theory as a method for discriminating among the opportunistic and advantageous uses of earnings management. They indicated that companies where earnings management is handled to a greater (less) degree would incur less (more) agency costs. Based on the agency theory, management gives rise to an opportunity for managers to pick and apply accounting figures and strategies that will maximize their own wealth. This topic has become more relevant in recent years as more companies are listed on the stock market as public companies (Kazemian \& Sanusi, 2015).

Earnings management often concerns the efforts of business executives or the misuse of earnings by executives in financial statements (Tangjitprom, 2012), where agency conflict occurs when executives opportunistically exploit earnings management in their own favor (Sun et al., 2010). Information asymmetry could lead to earnings management growing. Management gain more information and are better versed with the condition of the company compared to owners (Davidson et al., 2004). This opinion results in opportunist acts taken by earnings management based on their information asymmetry, in order to self-benefit. This study will inspect earnings management as information signalling to portray the business model of the company, and financial health.

\section{Signalling Theory}

The development of signalling theory was originally to explain the asymmetrical information in the labour market (Spence, 1973). In addition to that, it is also used to examine voluntary discovery in the reporting of corporations (Ross, 1977). This theory debates the fact that the presence of asymmetric information could also be a reason that moral corporations use financial information to send market signals (Ross, 1977). Any information disclosed to the market by the managers reduces asymmetrical information, which is deemed as a positive market signal. Market efficiency means, to some degree, that investors are rational at any given time and that values, based on a single stock or market, essentially integrate all the available information (Fama, 1970). However, as a result of the information asymmetry between management and owners, managers are working on their own behalf to select accounting strategies and calculations and, in exchange, can mask the true economic worth of the company. Prior et al. ( 2007) suggest that managers can take discretionary action to manipulate earnings in an effort to transmit favorable or unfavorable information on the future prospects of the company to capital markets. The chance to manage reported earnings captures the financial reserves of the company and shifts in business stock valuation, which are discretionary from actual cash flows (Sun et al., 2010). Earnings management may signal to investors the possibility of improve earnings and cash flow in the future.

The management of a company engage in earnings management with the intention of signalling their performance (Sun \& Rath, 2008). Furthermore, signalling theory shows that managers edit and change earnings to show the companies' inside information and their prospect (Connelly et al., 2011). Thus, aiding as a signalling mechanism, 
which is why managers partake in earnings management, in order to create a growing and smooth string of earnings over a period, which enables them to alter the price of the stock.

\section{Financial Factors Affecting Earnings Management and Earnings Quality}

The policy selection of accounting by managers from current accounting standards is known as earnings management, where they naturally are able to attain maximum utility and corporate value. Based on a few international comparative studies, earnings management has shown to be significant and productive (Almarayeh et al., 2020; Habib et al., 2013; Wysocki, 2011). Companies are able to utilise multiple strategies of earnings management that is accruals-based in order to manage their earnings (Braam et al., 2015). The discretion of management betters the ability of earnings, in term of accrual earnings management; allow it to portray economic value. Evidence of pervasive smoothing of income is present, allowing room for improvement of the perseverance and expectedness of reported earnings.

According to Subrmanyham (1996), the reflection of earnings in economic value and assistance in predicting future cash flows, earning and dividends is due to managerial accrual discretion. Subramanyam (1996) found evidence that is dependable on this hypothesis, suggesting that discretionary accruals enhance informational content to earnings. Lipe (1990) proposed that a technique to reduce earnings variability is earnings management, giving the stockholder an advantage to reduce their uncertainty allowing room to improve the predictability of future earnings.

In addition, earnings quality is a marker of financial reporting quality. The earnings quality consists of a discretionary and a nondiscretionary portion (Francis et al., 2004). The discretionary component is based on the process of financial reporting, while, in contrast, the nondiscretionary component is determined by the environment and business model. In terms of long-term future operating performance, as well as the company's valuation, earnings quality is a good measure and indicator. High quality earnings in a company can precisely indicate the current operating performance or its value. Therefore, high-quality earnings are often referred to as sustainable earnings. On the other hand, low quality earnings occur when they are managed. Managed earnings are the result of management's deliberate interference in the financial reporting process in order to achieve any private benefits (Schipper, 1989).

Empirical literature (such as: Cheng et al., 2019; Chan et al., 2015; Ecker et al., 2006; Francis et al., 2005; Easley \& O'Hara, 2004; Dechow \& Dichev, 2002) discussed the role of earnings quality in the business environmental. Cheng et al. (2019) and Chan et al. (2015) documented that there is positively link between earnings quality and investors' confidence about earnings information, where the earnings quality provides true information about financial misstatements, and this is will increase investors' confidence about earnings information. They also confirmed that the investors can use earnings quality as an indicator to predict future companies' returns. Francis et al. (2005) mentioned that there is negative relationship between earnings quality and cost of capital. The higher the earnings quality is, the lower the cost of capital is; because the costs of equity and costs of debt will be lower with the discounts that provided to the companies as a result of higher earnings quality in their information (Beyer et al., 2019; Perotti \& Wagenhofer, 2014).

Moreover, Mitra (2016) documented that company-specific return volatility is negatively affected by earnings quality, where the earnings quality uses to predict future dividend-paying ability, thus the investors can use it in preparing financial forecasts about the returns (Dempster \& Oliver, 2019). Healy and Whalen (1999) discussed that there is positive relationship between earnings quality affected by managerial behavior and the companies' performance, where the higher earnings quality refers to the sound managerial behaviour, and this is will improve the companies' performance (Machdar et al., 2017). Machdar et al. (2017) added that the operational performance in the companies positively and negatively affected by earnings quality and real earnings management, respectively.

With regard to prior literature, a variety of financial variables were included in the model, which indicate the characteristics of a company and their incentives of earnings management, and that may affect the quality of earnings.

Company size: Company size was regularly used in past research of earnings management. Although Jeong and Rho (2004) and Nuryaman (2009) suggest that larger companies tend to alter earnings to report more predictable earnings, some other studies (Krishnan, 2003; Park \& Shin, 2004; Piot \& Janin, 2007; Sánchez-Ballesta \& GarcíaMeca, 2007) indicate that large companies participate in earnings management to a much lower extent. Such mixed researches imply that there is no a direct correlation between the relationship of the company's size and their earnings management.

Working capital: The difference between a company's current assets and its current liabilities is referred to as working capital. Its function is primarily to support the company's daily financial operations, such as the payment of salaries, wages and other business expenses, the purchase of stock, as well as the financing of credit sales. Working capital may be described as the available capital for a company's day-to-day activities represented by its net current assets (Adeniji, 2008). 
The working capital is the central nervous system of a company and can directly address a companies' investment in short-term assets. Assets that can be transformed in an accounting year are known as current assets. Akinsulire (2008) refers to working capital as the items needed for the day-to-day production of products to be sold by a company whereby it is described as total surplus current assets over current liabilities. According to Kothari et al. (2004), managers are usually expected to reserve accruals for use in prospective earnings management, instead of substantially achieving incentive earnings expectations.

Leverage: Leverage is used to calculate the amount necessary to fund a company. Many studies determined that companies suffering financially often manage earnings downwards to exploit restructuring debt (Bassiouny et al., 2016; Gombola et al., 2016; Iman \& Nejad, 2015). Thus, leverage has a positive relationship with earnings management. In addition, Alzoubi (2017) examined the impact of debt financing on earnings management and found that high debt would increase earnings management risk. However, another perspective considers highly leveraged companies are under close examination from their lenders, which, therefore, decreases earnings management (Park \& Shin, 2004).

Cash: Companies avoid external capital due to information asymmetry and managers accumulate excess cash to pursue their own interest, according to pecking order theory. Managers are carrying less cash due to their desire for investment spending. Earnings management through discretionary accruals reduces cash valuations (Alhadab et al., 2015; Sun et al., 2012). Managers of struggling companies attempt to meet their objectives without considering the negative impact on the value of the company, by engaging in income increasing activities. From a shareholders' perspective, high resource allocation control by managers results in concerns regarding whether the excess cash invested in a project will increase the company value. Managers are using earnings management for signalling purpose and excess cash enables the managers to manipulate the earnings and, thereby, earn more profits (Kolb, 2006).

Growth: It is the valuation that demonstrates how much the company has grown from the time the company was founded to the current point in time. Zouari et al. (2012) stated that, with high growth, managers tend to lower companies' profits, which will then be allocated at a time when the company is experiencing a decrease in growth. Therefore, based on this backdrop, empirical studies found a positive relation between the company's growth rate and earnings management (Albersmann \& Hohenfels, 2017; Gul et al., 2009; Menon \& Williams, 2004; SáenzGonzález \& García-Meca, 2014).

Company performance: Profitability ratios are used to measure the company's ability to obtain profit during a certain period. According to Gunawan et al. (2014), the manager would accept earnings management to increase company's performance. Besides, Abdul Rahman and Ali (2006) indicated that companies with poorer performance are more motivated to manipulate earnings. However, other studies (e.g. DeGeorge et al., 1999) documented that highly successful businesses tend to manipulate their earnings figures. Furthermore, Sucuahi and Cambarihan (2016) examined the impact of company performance on earnings quality and found that company performance has a positive impact on earnings quality. On the other hand, Ali (2015) and Debnath (2017) found that company performance affects earnings management negatively. Therefore, the current study anticipates a relationship between company performance and earnings management.

Earnings per share: Almaryani et al. (2016) found that the financial reports were affected by earnings management practices, as well as the earnings management practices will affect the share prices and the shares return for those companies. Beneish and Vargus (2002) mentioned that, in the short term, the shares return was not disclosed by investors due to their perception that increasing the income leads to positive reactions in the market regarding earnings management. Baber et al. (2006) also mentioned that accrual components tend to deceive investors in the short term. In addition, Cruz and Luiz (2015) argued no significant impact for earnings management on short-term shares return, wherein it does not respond to evidence of earnings management. This is because the incentives around earnings management are well-understood by market participants. Moreover, it appears that investors are able to 'see through' financial data and, therefore, are able to manage their expectations in the presence of earnings management.

On the other hand, Sayari et al. (2013) argued that there is a negative effect for earnings management practices in large companies on their shares' return. In comparison, the earnings management activities in those companies have been eroded, but the yield on their shares has improved, although the management activities have not appeared in small companies. Balsam et al. (2002) revealed that the stock price has been negatively affected by earnings management. This is because investors use the financial and nonfinancial information in order to take their investment decision. They also re-evaluate reported accounting information, and, thus, make adjustment for investment decision as to stock prices. On the basis of the above arguments, the current study presents the following hypotheses: 
H1: Company's size, working capital ratio, current liabilities to total assets ratio, cash to current assets ratio, company's growth, ROA, and EPS affect earnings management.

H2: Company's size, working capital ratio, current liabilities to total assets ratio, cash to current assets ratio, company's growth, ROA, and EPS affect earnings quality.

\section{Earnings Management and Earnings Quality}

Details on the results of the company, which is given to shareholders, is often difficult to grasp in terms of its efficiency and consistency. Based on Leland and Pyle (1977), the state of information asymmetry refers to a conflict of interest between management and owners of the company. Furthermore, Huang and Skantz (2008) and Li (2014) reported that as insiders, managers use the information advantage to the disadvantage of external owners as a group, since managers and principals (owners) have separate priorities. However, the information provided by managers does not agree with the real requirements, since managers want their own incentives to be sought. In the other hand, one of the major indicators for accurately assessing a company's worth is earnings quality (Li, 2014).

Dechow et al. (2010) clarified that high earnings quality offers more knowledge on the success of a business that is important to a particular decision taken by a particular decision-maker. Furthermore, Demerjian et al. (2013) believed that the high earnings quality accurately reflects the company's operating performance. With that, McNichols (2002) and Beyer et al. (2019) documented that earnings management affects the magnitude of investors' uncertainty. At the same time, ignoring the possibility of reporting distortions affect earnings quality, because the bias in the estimates plays an important role in the reporting quality that is provided to investors.

In line with the previous studies, the purpose of this study is to investigate the influence of earnings management on the quality of earnings, and then the role of earnings management as a mediator in the impact of financial factors on the quality of earnings. It provides some empirical evidences. Some previous studies, such as McNichols (2002), recommended for future research providing more empirical evidence in the field of the earnings management and earnings quality, and more explanations about it. Thus, the study hypotheses are formulated as follows:

H3: Earnings management negatively affects earnings quality.

H4: Earnings management mediates the effect of company's size, working capital ratio, current liabilities to total assets ratio, cash to current assets ratio, company's growth, ROA, and EPS on earnings quality.

\section{Methodology}

This section includes an overview of the methods used in the study to analyze the effects of financial factors on the earnings management and earnings quality of insurance companies, using models of multivariate regression and econometrics. This section starts by discussing population and sample of the study, measurement of variables, and testing the validity of data for statistical analysis.

\section{Population and Sample}

Study population includes all Jordanian insurance companies listed in Jordanian market at the end of the year 2019, which totalled 24 companies. Four Jordanian insurance companies are omitted from the sample population because those companies do not have adequate data to cover the study period. The study covered the period from the year 2009 to the year 2018, and uses a panel data basis. On the other hand, our sample consists of 20 Jordanian insurance companies, giving a total of 200 observations for each variable.

\section{Measurement of Variables}

This study aims to investigate the effect of financial factors on both the earnings management and earnings quality, respectively. Then, it investigates the role of earnings management as a mediator in the effect of financial factors on earnings quality. The model of this study presents as the following figure: 


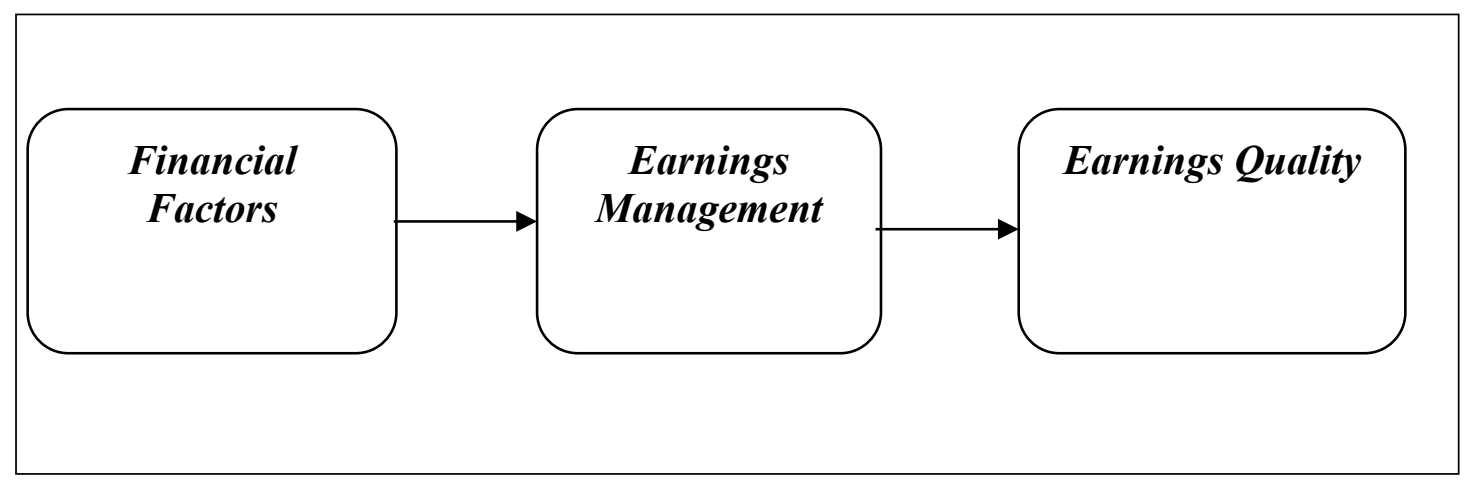

Figure 1. Study model

The current study focuses on the key financial factors supported by the previous literature and that are believed to be of interest for interested parties, namely company's size (Size), working capital ratio (WC), current-debt to total assets ratio (CDtoTS), cash to current assets ratio (CAtoCS), growth, return on assets (ROA), and earnings per share (EPS). These factors are measured as follows:

Size measured by natural logarithm (ln) of total assets (Devin et al., 2019), including total current assets and total non-current assets in the company (Devin et al., 2019; Kieso et al., 2012), as in the following equation:

$$
\text { Size i. } \mathrm{t}=\ln \text {. (Total Assets) }
$$

where, Size is natural logarithm for the company $i$ for the year $t$.

WC is also called the current ratio. It is calculated through total current assets divided by total current-debt (Al Qaisi et al., 2016), as in the following equation:

$$
\text { WC i. } t=\frac{\text { Total Current Assets }}{\text { Total Current Debt }}
$$

where, WC is for the company i for the year t.

CDtoTS ratio is determined on the basis of total current-debt divided by total assets and displays the proportion of assets funded by current-debt (Mboi et al., 2018), as the following equation:

$$
\text { CDtoTS i. } \mathrm{t}=\frac{\text { Total Current Dept }}{\text { Total Assets }}
$$

where, CDtoTS is for the company $i$ for the year $t$.

CAtoCS refers to an indicator that helps the interested parties to consider the proportion of cash residing in current assets, as well as it is a prudent indicator of a company's ability to pay off liabilities (Shehadeh, 2011). It is calculated through cash to total assets (Cleary \& Sonmez, 2016), as in the following equation:

$$
\text { CAtoCS i. } \mathrm{t}=\frac{\text { Cash }}{\text { Total Current Assets }}
$$

where, CAtoCS is for the company $i$ for the year $t$.

Growth factor is calculated by the percentage change in total assets for the company during the study period (DeAngelo et al., 2006), as in the following equation:

$$
\text { Growth i. } \mathrm{t}=\frac{\text { Total Assets at the Current period }- \text { Total Assets for Previous period }}{\text { Total Assets for Previous period }}
$$

where, Growth is for the company $i$ for the year $t$. 
ROA is an indicator for a profitability that provides how much earnings a company is able to generate from its total assets (Brigham \& Besley, 2011; Devin et al., 2019; Kabajeh et al., 2012; Kathuo, 2015; Zutter \& Gitman, 2012). ROA is measured by the following equation:

$$
\text { ROAi. } \mathrm{t}=\frac{\text { Company's Earnings (Net income) }}{\text { Total Assets }}
$$

where, ROA is for the company $i$ for the year $t$.

As well, EPS is a company's earnings per outstanding share of common stock for a company (Almumani, 2014; Geetha \& Swaaminathan, 2015), as in the following equation:

$$
\text { EPSi. } \mathrm{t}=\frac{\text { Company's Earnings (Net income) }}{\text { Number of Common Stock Shares it has Outstanding }}
$$

where, EPS is for the company i for the year $t$.

In addition, the study used modified Jones model to measure the earnings management (Dechow et al., 1995; Jones, 1991). The modified Jones model was used by prior researches, such as Niu (2006), Chang and Sun (2009), Jaggi et al. (2009), Sun et al. (2010), Sun and Liu (2011), Al Saedi (2018), and Almarayeh et al. (2020). This model is used to calculate non-discretionary accruals to detect earnings management, and, thereby, Alluzi (2013) has documented that the modified Jones model is the best in this area. According to the modified Jones model, earnings management $(\mathrm{EM})$ is calculated through the following steps:

Step 1: Measure total accruals by the difference between operating net profit and operating cash flow through the following equation:

$$
\text { TACCi.t }=\text { ONIi.t }- \text { OCFi.t }
$$

where, TACCi.t is total accruals for the company $i$ for the year t, ONIi.t is operating net profit for the company $i$ for the year $t$, as well as OCFi.t is operating cash from for the company $i$ for the year $t$.

Step 2: Non-discretionary accruals (NDACCi.t) are calculated by the following regression equation of the sample for each year.

$$
\begin{aligned}
& \text { TACCi.t/Ai.t-1=a1(1/Ai.t-1)+a2 }((\boldsymbol{\Delta} \text { REVi.t- } \mathbf{\Delta} \text { RECi.t)/Ai.t-1)+a3 (PPEi.t/Ai.t1 })+\varepsilon \\
& \text { NDACCi.t/Ai.t-1= a1(1/Ai.t-1)+a2 }((\boldsymbol{\Delta} \text { REVi.t- } \mathbf{\Delta} \text { RECi.t)/Ai.t-1)+a3 (PPEi.t/Ai.t-1) }
\end{aligned}
$$

where, TACCi.t is total accruals for the company i for the year t, $\Delta$ REVi.t is the change in revenue for the company $i$ for the year t, $\mathbf{\Delta}$ RECi.t is the change in receivables for the company $i$ for the year t, PPEi.t is the properties, plants and equipment for the company $i$ for the year t, Ai.t-1 is total assets for the company $i$ for the year $t-1, \varepsilon$ is the random error, and NDACCi.t is non-discretionary accruals for the company i for the year $t$.

Step 3: Discretionary accruals are measured by the following equation:

$$
\text { DACCi.t }=(\text { TACCi.t/Ai.t-1 })-(\text { NDACCi.t/Ai.t-1) }
$$

where, DACCi.t is discretionary accruals for the company i for the year $t$.

Concerning the measurement of earnings quality (EQ), Abu Ali (2011), Jafari (2016), Alsufy et al. (2020) and Afifa et al. (2020) documented that the cash approach model is used as a measurement of earnings quality. They also documented that the closer the accounting profit to cash reflects a high quality, and this measurement is adopted in the current study. It is concerned with measuring the predictive power of earnings quality. We can present the earnings quality measurement by the following equation: 


$$
\begin{gathered}
\text { OCFtoTAi. } \mathrm{t}=\frac{\text { Operating Cash Flow }}{\text { Total Assets }} \\
\text { NItoTAi. } \mathrm{t}=\frac{\text { Net Income }}{\text { Total Assets }} \\
\text { EQi.t }=\frac{\text { OCFtoTAi.t }}{\text { NItoTAi.t }}
\end{gathered}
$$

where, OCFtoTAi.t is the ratio of dividing the operating cash flow by total assets for the company $\mathrm{i}$ in the year $\mathrm{t}$, NItoTAi.t is the ratio of dividing the net income by total assets for the company $i$ in the year $t$, and then EQi.t is the result of dividing OCFtoTAi.t by NItoTAi.t for the company $i$ in the year $t$.

\section{Data Validity}

Before testing the hypotheses, linear regression has a set of assumptions that must be met. For instance, it's important to execute the following tests in order to judge the validity of data:

\section{Multicollinearity}

The validity of the regression model depends on the presumption of the independence of each of the independent variables. If this assumption is not achieved, the model cannot be considered appropriate. Multiple linear correlation problem arises when the correlation strength between the independent variables used in the regression model increases more than 0.8 . This problem affects the process of estimating model parameters; therefore, it affects the efficiency of the model in general (Guajarati, 2004). Two methods are used to detect the problem of multiple linear correlation. The first is the Pearson correlation test between the independent variables in the regression model, whereby Brayman and Cramer (2001) believe that, if the correlation coefficient exceeds 0.8 between the independent study variables, this is an indication of the presence of multicollinearity. The second method is to find the Variance Inflation Factor (VIF) and tolerance, where the VIF shows how the high correlation increases the instability of the estimated coefficients and is a measure that is made for each variable separately.

The results in Table 1 show no multicollinearity among independent variables, where the Pearson correlation coefficient appears between -0.407 to 0.475 . In addition, Table 2 presents that VIF and tolerance values for all variables in the study model were less than 10 , and more than 0.2 , respectively. This means that panel data models in the current study do not suffer from any multicollinearity problems.

Table 1. Person correlation matrix

\begin{tabular}{lcccccccc}
\hline Variable & Size & WC & CDTOTS & CATOCS & GROWTH & ROA & EPS & EM \\
\hline Size & 1.000 & & & & & & & \\
WC & -0.356 & 1.000 & & & & & & \\
CDtoTS & 0.211 & -0.407 & 1.000 & & & & & \\
CAtoCS & 0.205 & -0.226 & -0.119 & 1.000 & & & \\
GROWTH & 0.260 & 0.018 & 0.036 & 0.256 & 1.000 & & & \\
ROA & 0.247 & -0.071 & -0.061 & 0.235 & 0.263 & 1.000 & & \\
EPS & 0.459 & -0.083 & -0.068 & 0.216 & 0.438 & 0.475 & 1.000 & \\
EM & 0.341 & -0.111 & -0.063 & 0.074 & 0.214 & 0.234 & 0.306 & 1.000 \\
\hline
\end{tabular}


Table 2. Collinearity statistics

\begin{tabular}{lcc}
\hline Variable & VIF & Tolerance \\
\hline Size & 1.592 & 0.628 \\
WC & 1.469 & 0.681 \\
CDtoTS & 1.371 & 0.729 \\
CAtoCS & 1.258 & 0.795 \\
GROWTH & 1.353 & 0.739 \\
ROA & 1.339 & 0.747 \\
EPS & 1.769 & 0.565 \\
EM & 1.218 & 0.821 \\
\hline
\end{tabular}

\section{Stationary Test}

Time series analysis is one of the statistical approaches that discusses the behavior and perception of phenomena over long periods of time. The consistency of the time series is an important problem in many applications that follow panel data, since the uncertainty of the data provides misleading results for the values of $\left(\mathrm{R}^{2}\right)$ and $(\mathrm{F})$.

Unit root test was performed in order to test stability of time series. A Levin-Lin-Chu test was performed to test whether the study variables contained the unit root. When the Levin-Lin-Chu test is performed with the unit root, the significance level will be above 5\%. Table 3 shows that p-value for all variable is less than $5 \%$, and this ensures that all variables are stable over time, and, therefore, we reject the hypothesis of the existence of the unit root.

Table 3. Levin-Lin-Chu test

\begin{tabular}{lcc}
\hline Variable & P-Value & Statistic \\
\hline Size & 0.000 & -5.614 \\
WC & 0.000 & -4.555 \\
CDtoTS & 0.000 & -3.302 \\
CAtoCS & 0.000 & -6.273 \\
GROWTH & 0.000 & -11.130 \\
ROA & 0.000 & -12.628 \\
EPS & 0.000 & -4.972 \\
EM & 0.000 & -4.972 \\
EQ & 0.000 & -8.126 \\
\hline
\end{tabular}

\section{Data Analysis and Testing}

\section{Descriptive Results}

Table 4 shows the findings of descriptive analysis tests. It shows that the mean of Size of those companies during the study period was 17.0864 with SD 0.6458 . The mean of WC was 2.3127 with SD 1.0596 , whereby it illustrates that those companies have ability to pay off current liabilities with current assets. Then, the mean of CDtoTS was 0.1125 with SD 0.0612. In the other words, the percentage of those companies' assets financed with current-debt was $11.25 \%$. The mean of CAtoCS was 0.1503 with SD 0.1414. It indicates that the proportion of cash residing in current assets of those companies during the study period was $15.03 \%$. Further, the mean of GROWTH was 0.0500 with SD 0.1037 . This means that the total assets of those companies increased during the study period by $5 \%$. The mean of ROA was 0.0230 with SD 0.1408 , at the same time the mean of EPS was 0.0464 with SD 0.1185 . The last two indicators illustrate the financial performance for those companies during the study period.

Additionally, the mean of EM was -0.0046 with SD 0.0027 . This indicates that, as a general figure, there are negative earnings management practices in those companies during the study period, where those companies aimed to reduce their income instead of increasing it. However, these practices are relatively few because the mean value is closer to 0 during the study period. The mean of EQ was 0.2438 with SD 2.7223 , where it also confirms that there are few earnings management practices because the closer of the accounting profit to cash reflects a high quality. In 
the other words, when EQ is closer to 1, it reflects a high quality and the mean value for EQ indicates that the earnings of those companies are not at a high quality level.

Table 4. Descriptive statistics

\begin{tabular}{lcc}
\hline Variable & Mean & St. Deviation (SD) \\
\hline Size & 17.0864 & 0.6458 \\
WC & 2.3127 & 1.0596 \\
CDtoTS & 0.1125 & 0.0612 \\
CAtoCS & 0.1503 & 0.1414 \\
GROWTH & 0.0500 & 0.1037 \\
ROA & 0.0230 & 0.1408 \\
EPS & 0.0464 & 0.1185 \\
EM & -0.0046 & 0.0027 \\
EQ & 0.2438 & 2.7223 \\
\hline
\end{tabular}

\section{Regression Results}

Panel data contain observations of various phenomena gathered over various time intervals within the same company by integrating time-series and cross-section data. The idea of integrating time-series and cross-section data is to arrive at a better model estimation; in comparison, panel data include more informative data, more variability, less collinearity between variables, more freedom and more reliability (Baltagi, 2005). Further, the methodology of the study relied on collecting financial data on time-series data extending from the year 2009 to the year 2018, which is also cross-sectional data where the study sample included 20 companies. Thus, each company represents a crosssection.

Regression models are divided into two models, namely the Fixed Effect model, and the Random Effects model. A Haussmann test is conducted to choose either of the two previous models to test the panel data. Null hypothesis (H0) indicates to accept the random effects model versus the alternative hypothesis (H1) which indicates acceptance of the fixed effects model. If the value of Prob-value is more than 5\%, the random effects model will be chosen, and then, if the value of Prob-value is less than 5\%, the fixed effect approach will be selected (Baltagi, 2005).

Table 5 indicates that the value of the Chi-Square statistic amounted to 11.953 and the Prob-value, reached 0.102. Therefore, the null hypothesis is accepted, and that the appropriate estimation method is a random effects method. In the other words, this study adopted a random effect approach in order to test its hypotheses and achieve its objectives.

Table 5. Hausman test

\begin{tabular}{lccc}
\hline \multicolumn{4}{c}{ Correlated Random Effects - Hausman Test } \\
\hline & Test cross-section random effects & & \\
Test Summary & Chi-Sq. Statistic & Chi-Sq. & Prob. \\
Cross-section random & 11.953 & 8 & 0.102 \\
\hline
\end{tabular}

The first objective of this study is to examine the effect of financial factors on earnings management. The second objective is to examine the effect of financial factors on earnings quality. The third objective is to investigate the impact of earnings management on earnings quality. Then, the last objective is to examine the role of earnings management as a mediator in the effect of financial factors on earnings quality. Therefore, four different regression models based on panel data basis are estimated. The following parts present the results of the regression models.

H1: Company's size, working capital ratio, current liabilities to total assets ratio, cash to current assets ratio, company's growth, ROA, and EPS affect earnings management.

Table 6 shows that the Adjusted R-square of the model is 0.152, which means that the model explains $15.2 \%$ from the changes in earnings management, whereas Prob (F-statistic) is 0.000 , which means that all financial factors in the model combined affect the earnings management. Consequently, the results display Size, CAtoCS, GROWTH, and ROA separately have effects on earnings management. At the same time, the results report WC, CDtoTS, and EPS 
separately does not have effects on earnings management. As a conclusion, the first null hypothesis is partially rejected.

To some extent, these results match with the work of DeGeorge et al. (1999), Jeong and Rho (2004), Nuryaman (2009), Gunawan et al. (2014) and Dang et al. (2017), where they documented that the link between performance indectators and earnings management is positive. The high companies performance encourages to manage their earnings figures. As well, Jeong and Rho (2004) and Nuryaman (2009) found that the earnings management increases in the larger companies compared to other, where the large number of the operational transactions in these companies contributes to reduce the control levels, hence the earnings management practices will increase. This result is also suitable with results of Kothari et al. (2005), Barto and Simko (2002), Myers and Skinner (2000). While Krishnan (2003), Park and Shin (2004), Piot and Janin (2007) and Sánchez-Ballesta and García-Meca (2007) have reported that earnings management activities in large companies would be constrained because control practices (such as governance) are stronger in these companies than in small companies. Also, Abdul Rahman and Ali (2006), Ali (2015) and Debnath (2017) argued that the companies that achived lower performance have more motivation to manage earnings, where managers of these companies aim to increase the performance through manage earnings in order to beautify the image of companies.

Moreover, the results also match with the work of Cruz and Luiz (2015), Bassiouny et al. (2016), Gombola et al. (2016), and Iman and Nejad (2015). According to Cruz and Luiz (2015), no significant link between short-term shares return and earnings management, where it does not respond to evidence of earnings management, as well as investors are able to manage their expectations in the presence of earnings management. Additionally, Bassiouny et al. (2016), Gombola et al. (2016), and Iman and Nejad (2015) documented that companies facing financial hardship tend to manage their earnings. Alzoubi (2017) also mentioned that high debt in the companies contributes to increase earnings management practices. In contrast, Park and Shin (2004) argued that there is negative relationship between the companies' debt and earnings management practices, as a result to close examination from their lenders. At the same time, Charfeddine at et (2013), Fathi (2013). Alsharairi and Salama (2012) and Shen and Chih (2007) have agreed that there is a negative association between financial leverage and earnings management.

Table 6. Regression results of the first hypothesis

\begin{tabular}{|c|c|c|c|c|}
\hline Variable & Coefficient & Std. Error & t-Statistic & Prob. \\
\hline $\mathrm{C}$ & -0.025 & 0.009 & -2.759 & $0.006^{* * *}$ \\
\hline Size & 0.001 & 0.001 & 2.367 & $0.019 * *$ \\
\hline WC & 0.000 & 0.000 & -0.027 & 0.979 \\
\hline CDtoTs & -0.005 & 0.004 & -1.363 & 0.175 \\
\hline CAtoCS & -0.004 & 0.001 & -2.930 & $0.004 * * *$ \\
\hline GROWTH & 0.003 & 0.002 & 1.980 & $0.049 * *$ \\
\hline $\mathrm{ROA}$ & 0.003 & 0.001 & 2.456 & $0.015 * *$ \\
\hline EPS & 0.002 & 0.002 & 0.998 & 0.319 \\
\hline R-squared & \multicolumn{4}{|c|}{0.184} \\
\hline Adjusted R-squared & \multicolumn{4}{|c|}{0.152} \\
\hline F-statistic & \multicolumn{4}{|c|}{5.824} \\
\hline Prob (F-statistic) & \multicolumn{4}{|c|}{$0.000 * * *$} \\
\hline$*, * *, * * *=$ p-value $<.10, .05, .01$ & & & & \\
\hline
\end{tabular}

H2: Company's size, working capital ratio, current liabilities to total assets ratio, cash to current assets ratio, company's growth, ROA, and EPS affect earnings quality.

Table 7 shows that Adjusted R-square of the model is 15.1, which means that the model explains $15.1 \%$ from the changes in earnings quality. The results also show that Prob (F-statistic) is 0.000 , which means that all financial factors in the model combined affect the earnings quality. Equally importantly, the results indicate a negative significant effect for size and working capital separately on earnings quality. At the same time, there are no significant effects for CDtoTS, CAtoCS, GROWTH, ROA, and EPS separately on earnings quality. Therefore the second null hypothesis is partially rejected. 
These results are somewhat consistent with the findings of Dechow et al. (2010) and Li (2014). For example, Li (2014) confirmed that we can evaluate the value of a company through its earnings quality. Furthermore, Demerjian et al. (2013) also documented that there is positive relationship between the company's operating performance and earnings quality, whilst the results of the current study indicate that no significant effects for company's performance proxies (such as ROA and EPS) on earnings quality.

Table 7. Regression results of the second hypothesis

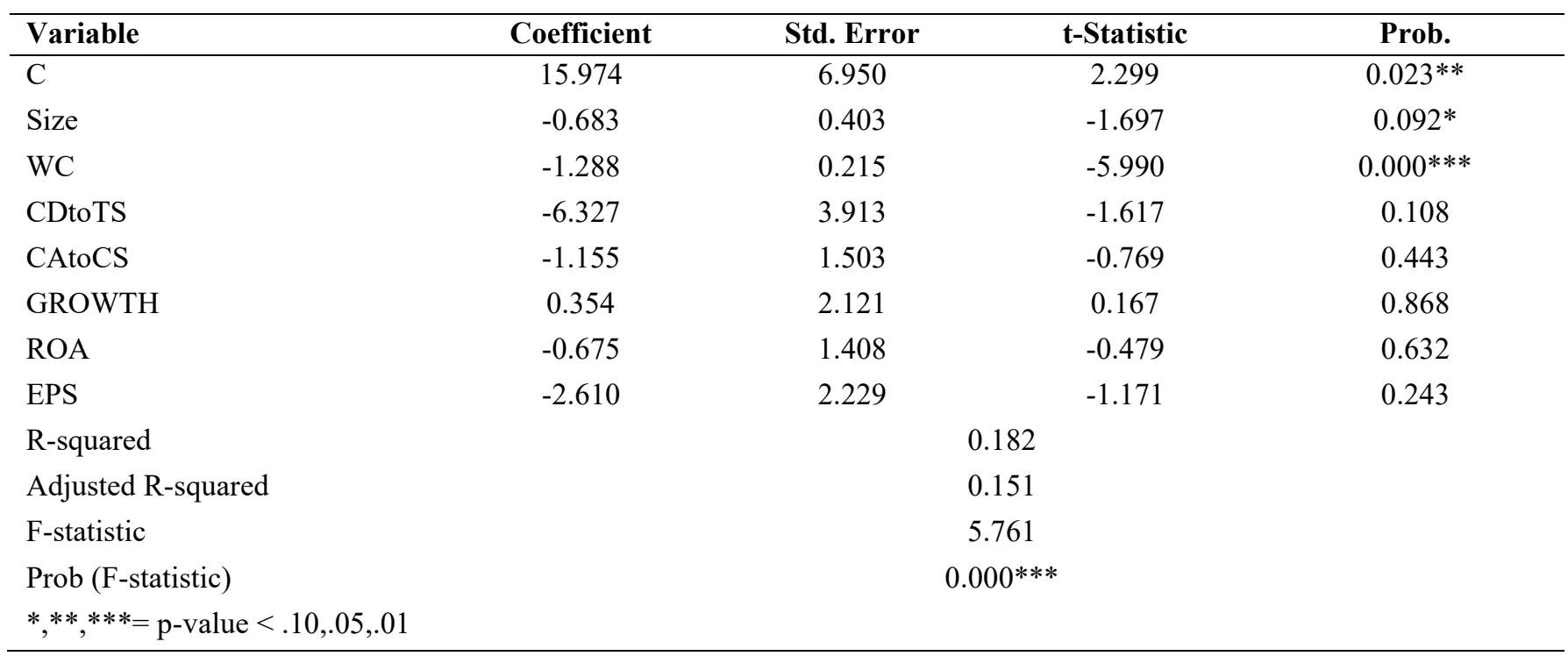

H3: Earnings management negatively affects earnings quality.

Table 8 shows the relation result between earnings management and earnings quality, and the results show that the R-square of the model is only 0.026 , which means that earnings management only explains $2.6 \%$ from changes in the earnings quality. Prob (F-statistic) is 0.028 and this relation is a negative. Thus, the third null hypothesis is rejected. In the other words, the earnings management negatively affects earnings quality, and a high earnings management reflects low earnings quality level. This result highly matches with the work of McNichols (2002), Ahmadpour and Shahsavari (2016), Chang et al. (2016), and Beyer et al. (2019). They documented that the bias in the estimates negatively affects the reporting quality that is provided to interested parties, such as investors. Chang et al. (2016) also mentioned that a flexibility in reporting negatively affects earnings quality, hence its utility in the decision-making process will be limited. Additionally, they documented that, the higher a flexibility in reporting is, the higher the earnings management is, and thus a flexibility in reporting is a proxy for the earnings management.

Table 8. Regression results of the third hypothesis

\begin{tabular}{lcccc}
\hline Variable & Coefficient & Std. Error & t-Statistic & Prob. \\
\hline C & -0.545 & 0.414 & -1.315 & 0.190 \\
EM & -170.882 & 77.043 & -2.218 & $0.028^{* *}$ \\
R-squared & & 0.026 & 0.020 \\
Adjusted R-squared & & 4.933 & \\
F-statistic & & $0.028^{* *}$ & \\
Prob (F-statistic) & & & \\
$* * * * * *=$ p-value $<.10, .05, .01$ & & & \\
\hline
\end{tabular}

H4: Earnings management mediates the effect of company's size, working capital ratio, current liabilities to total assets ratio, cash to current assets ratio, company's growth, ROA, and EPS on earnings quality. 
Table 9 shows that the Adjusted R-square of the model is 0.155 , which means that the model explains $15.5 \%$ from the changes in earnings quality, and this indicates that inserting of earnings management as a mediator variable improves the explanation power of the model. In addition, the Prob (F-statistic) for this model is 0.000 , and thereby the fourth null hypothesis is rejected. In the other words, low earnings management level with real financial factors contribute to better the quality of financial reporting in the companies. Alhadab et al. (2015), Fathi (2013) and Sun et al. (2012) mentioned that more liquid assets in the companies may be increase the earnings management through discretionary accruals, and thus this is will negatively affect the earnings quality. Continuously with discussion on the results of the first hypothesis, Alzoubi (2017) documented that the higher the debt financing is, the higher the earnings management is, and thus this is will negatively affect the quality of reporting. In contrast, Park and Shin (2004) mentioned that the quality of reporting will be high with highly leveraged companies, as a result to close examination from their lenders, where the close examination means decrease earnings management.

Table 9. Regression results of the fourth hypothesis

\begin{tabular}{lcccc}
\hline Variable & Coefficient & Std. Error & t-Statistic & Prob. \\
\hline C & 12.49393 & 7.005527 & 1.783439 & $0.0762^{*}$ \\
Size & -0.515201 & 0.402 & -1.281 & 0.202 \\
WC & -1.27946 & 0.213 & -6.004 & $0.000^{* * *}$ \\
CDtoTS & -6.734832 & 3.863 & -1.743 & $0.083^{*}$ \\
CAtoCS & -1.493989 & 1.498 & -0.998 & 0.320 \\
GROWTH & 0.771753 & 2.134 & 0.362 & 0.718 \\
ROA & -0.32246 & 1.420 & -0.227 & 0.821 \\
EPS & -2.387417 & 2.229 & -1.071 & 0.286 \\
EM & -138.18 & 81.517 & -1.695 & $0.092^{*}$ \\
R-squared & & & & \\
Adjusted R-squared & & 0.191 & & \\
F-statistic & & 0.155 & & \\
Prob (F-statistic) & \multicolumn{2}{c}{5.306} & & \\
$*, * * * * *=$ p-value $<.10, .05, .01$ & & $0.000^{* * *}$ & & \\
\hline
\end{tabular}

\section{Study Conclusions}

The current study aims to investigate the effect of financial factors on the earnings management and earnings quality, respectively by Jordanian insurance companies listed in Jordanian market at the end of the year 2019. Additionally, it investigates the role of earnings management as a mediator in the effect of financial factors on earnings quality. This study covered the period from the year 2009 to the year 2018, and uses a panel data basis.

The results of this study indicate that all financial factors in the model combined affect the earnings management. This means that the company's financial factors contribute to encouraging managers to manipulate earnings. All financial factors provide a complete image of the company's financial position, which determines the level and manner of earnings management practices. Such as, company size, cash to current assets ratio, company's growth, and ROA separately affects earnings management. Deeply, the results showed that there is a positive relationship between company size, company growth, and ROA separately with earnings management practices. In the other words, large-size companies, and companies that achieve high growth and profits have more earnings management compared to others. At the same time, there is a negative relationship between cash to current assets ratio and earnings management practices in the companies. The high cash to current assets ratio reduces the earnings management practices in the companies.

Consequently, all financial factors in the model combined affect the earnings quality. However, there is a negative effect for size and working capital ratio separately on earnings quality. This means that the large-size companies and the companies that have high working capital ratio have no more earnings quality compared to others, where the level of earnings management under these determinants is at a high level. Then, there is a negative effect for earnings 
management on earnings quality. The earnings management contributes to increase the expectations gap and the variation in future performance, and, thus, negatively affects the reporting and earnings quality.

Additionally, the study concludes that earnings management is fully mediated by the effect of all financial factors in the model combined on earnings quality. The working capital ratio and current liabilities to total assets ratio separately with the role of earnings management have negative effects on earnings quality. In the other words, high company's working capital ratio and high company's current liabilities to total assets ratio with high earnings management practices negatively affect the reporting and earnings quality.

Finally, these results that link with the financial determinants of earnings management and earnings quality are suitable with agency theory and signalling theory. Agency theory discussed that more control levels in the companies lead to presence real financial information, where the earnings management will be limited; hence the earnings quality will be high. In addition to that, signalling theory discussed that presence of asymmetric information could also be a reason that moral corporations use financial information to send market signals. More disclosures of true information reduce asymmetrical information, and thus this contributes to reduce the earnings management, as well as increase the earnings quality.

\section{Implications}

Following the global financial crisis (August 2008), earnings management activities were mostly dominated by governance-based companies that led managers to deliver more risky operations in a diluted ownership market and in an informational asymmetry situation marked by absence of the control. In addition, earnings management resulted from the conflict of interest between shareholders and managers, which led managers to achieve more personally aims. To circumvent the shareholders' supervisory power, managers manipulate earnings, offering a low level of risk, and circulating false beliefs for shareholders and other interested parties, and thus this is will negatively affect the quality of the accounting information that used in the decisions making. Besides, this was done when prudential supervision was weak, hence to reduce any earnings management, which the policy makers should account for, and thereby achieving transparency in the presentation of financial reports. The policy makers need to adopt good regulations to limit the company activities about earnings management, and thus make sure that the financial reports genuinely express the true situation of the company. Finally, this study will help investors and other interested parties in giving them a more broad comprehension and understanding into earnings management and earnings quality. Further study would be able to provide a broader view of the determinants of manipulation of earnings and earnings quality, especially in different areas, such as the MENA region.

\section{References}

Abbadi, S. S., Hijazi, Q. F., \& Al-Rahahleh, A. S. (2016). Corporate Governance Quality and Earnings Management: Evidence from Jordan. Australasian Accounting, Business and Finance Journal, 10(2), 54-75.

Abdul Rahman, R., \& Ali, F.H. (2006). Board, audit committee, culture and earnings management: Malaysian evidence. Managerial Auditing Journal, 21(7), 783-804.

Abdullatif, M. (2016). Auditing Fair Value Estimates in Developing Countries: The Case of Jordan. Asian Journal of Business and Accounting, 9(2), 101-140.

Abdullatif, M., \& Al-Khadash, H.A. (2010). Putting audit approaches in context: The case of business risk audits in Jordan. International Journal of Auditing, 14(1), 1-24. https: //doi.org/10.1111/j.1099-1123.2009.00400.x

Abu Ali, S., Al-Debi'e, M., \& Abu Nassar, M. (2011). The Impact of earnings quality on the cost of equity based on the international financial reporting standards. Jordan Journal of Business Administration, 7(1), 67-94.

Adeniji, A.A. (2008). Management Accounting (4th Edition). Lagos, Nigeria: El-Toda Venture Limited.

Afifa, M. A., Alsufy, F., \& Abdallah, A. (2020). Direct and Mediated Associations among Audit Quality, Earnings Quality, and Share Price: The Case of Jordan. International Journal of Economics \& Business Administration (IJEBA), 8(3), $500-516$.

Ahmadpour, A., \& Shahsavari, M. (2016). Earnings Management and the Effect of Earnings Quality in Relation to Bankruptcy Level (Firms Listed at the Tehran Stock Exchange). Iranian journal of management studies, 9(1), 77-99.

Akinsulire, C. (2008). Financial Management (5th edition). Lagos, Nigeria: Ceemol Nigeria Limited.

Al Qaisi, F., Tahtamouni, A., \& Al-Qudah, M. (2016). Factors Affecting the Market Stock Price - The Case of the Insurance Companies Listed in Amman Stock Exchange. International Journal of Business and Social Science, 7(10), 81-90.

Al Saedi, A.A. (2018). Earnings Management and its Relationship with Stock Returns: An Empirical Study on a Sample of Qatari Listed Industrial Companies. Academy of Accounting and Financial Studies Journal, 22(5), 1-12.

Albersmann, B. T., \& Hohenfels, D. (2017). Audit committees and earnings management-Evidence from the German two-tier board system. Schmalenbach Business Review, 18(2), 147-178. 
Alhadab, M., Clacher, I., \& Keasey, K. (2015). Real and accrual earnings management and IPO failure risk. Accounting and Business Research, 45(1), 55-92.

Ali, U., Noor, M. A., Khurshid, M. K., \& Mahmood, A. (2015). Impact of Firm Size on Earnings Management: A Study of Textile Sector of Pakistan. European Journal of Business and Management, 7(28), 47-56.

Al-khabash, A.A., \& Al-Thuneibat, A.A. (2008). Earnings management practices from the perspective of external and internal auditors: Evidence from Jordan. Managerial Auditing Journal, 24(1), 58-80. https://doi.org/10.1108/ 02686900910919901

Almarayeh, M., Abdullatif, T., \& Aibar-Guzmán, B. (2020). Does Audit Quality Influence Earnings Management in Emerging Markets? Evidence from Jordan. Revista de contabilidad spanish accounting review, 23(1), 64-74.

Almasarwah, A. (2019). Discretionary accruals and ownership structure: empirical study from Jordan International. Journal of Corporate Governance, 10(3/4), 209-247.

Al-Mousawi, R.J., \& Al-Thuneibat, A. (2011). The effect of audit quality on the earnings management activities. Dirasat: Administrative Sciences, 38(2), 614-628.

Almumani, M. (2014). Determinants of Equity Share Prices of the Listed Banks in Amman Stock Exchange: Quantitative Approach. International Journal of Business and Social Science, 5(1), 91-104.

Alsharairi, M., \& Salama, A. (2012). Does High Leverage Impact Earnings Management? Evidence from Non-Cash Mergers and Acquisitions. Journal of Financial and Economic Practice, 12(1), 17-33.

Alsufy, F., Afifa, M. A., \& Zakaria, M. (2020). Mediating Effects of Liquidity in the Relationship between Earnings Quality and Market Value of the Share Price: Evidence from Jordan. Review of Applied Socio-Economic Research, 19(1), 17-32.

Alzoubi, E.S.S. (2017). Audit quality and earnings management: evidence from Jordan. Journal of Applied Accounting Research, $17(2), 170-189$.

Baber, W.R., Chen, S., \& Kang, S.H. (2006). Stock price reaction to evidence of earnings management: Implications for supplementary financial disclosure. Review of Accounting Studies, 11(1), 5-19

Balsam, S., Krishnan, J., \& Yang, J.S. (2003). Auditor industry specialization and earnings quality. Auditing: A Journal of Practice \& Theory, 22(2), 71-97.

Baltagi, B.H. (2005). Econometric analysis of panel data (3rd edition). West Sussex: Wiley.

Barton, J., \& Simko, P.J. (2002). The Balance Sheet as an Earnings Management Constraint.The Accounting Review, 77(1), 127.

Bassiouny, S. W., Soliman, M. M., \& Ragab, A. (2016). The impact of firm characteristics on earnings management: An empirical study on the listed firms in Egypt. The Business \& Management Review, 7(2), 91-101.

Beneish, M. D., \& Vargus, M.E., (2002). Insider trading, earnings quality, and accrual mispricing, The Accounting Review, 77, 755-791.

Beyer, A., Guttman, I., \& Marinovic, I. (2019). Earnings Management and Earnings Quality: Theory and Evidence. The Accounting Review, 94(4), 77-101.

Braam, G., Nandy, M., Weitzel, U., \& Lodh, S. (2015). Accrual-based and real earnings management and political connections. The International Journal of Accounting, 50(2), 111-141.

Brigham, E.F., \& Besley, S. (2011). Principles of Finance ( $5^{\text {th }}$ edition). South-Western: Cengage.

Bryman, A., \& Cramer, D. (2001). Quantitative Data Analysis with SPSS Release 10 for Windows: A Guide for Social Scientists. London: Routledge.

Chan, L., Chen-K., Chen-T., \& Yu, Y. (2015). Substitution between Real and Accruals-Based Earnings Management after Voluntary Adoption of Compensation Clawback Provisions. The Accounting Review, 90, $147-174$. https://doi.org/10.2308/accr-50862

Chang, J.C., \& Sun, H.L. (2009). Cross-listed foreign firm's earnings informativeness, earnings management and disclosures of corporate governance information under SOX. The International Journal of Accounting, 44(1), 1-32.

Charfeddine, L., Riahi, R., \& Omri, A. (2013). The Determinants of Earnings Management in Developing Countries: A Study in the Tunisian Context. The IUP Journal of Corporate Governance, 12(1), 35-49.

Cheng, M.M., Dinh, T., Schultze, W., \& Assel, M. (2019). The Effect of Bonus Deferral on Managers' Investment Decisions. Behavioral Research in Accounting, 31(2), 31-49.

Cheng, X. S., Liu, J. M., \& Cheng, Y. (2015). A Supplement or Another Lie: Earnings Manipulation and Non-Financial Information Disclosure in MD\&A. Accounting Research, 8, 11-18.

Cleary, S., \& Sonmez, F., (2016). The Cash Effect and Market Reaction Over Three Decades. Journal of Accounting and Finance, 16(8), 93-115.

Connelly, B. L., Certo, S. T., Ireland, R. D., \& Reutzel, C. R. (2011). Signaling Theory: A Review and Assessment. Journal of Management, 37(1), 39-67.

Cruz, D., \& Luiz, A. (2015). Earnings Management Choice: An Empirical Study on the Impact of Earnings Management on Stock Returns in DLSU Research Congress. Jurnal akuntansi, 22(2), 173-191.

Dang, N. H., Hoang, T. V. H., \& Tran, M. D. (2017). Factors Affecting Earnings Management: The Case of Listed Firms in Vietnam. International Journal of Economic Research, 14(20), 117-134.

Davidson, R., Goodwin-Stewart, J., \& Kent, P. (2005). Internal governance structures and earnings management. Accounting and Finance, 45(2), 241-267. 
DeAngelo, H., DeAngelo, L., \& Stulz, R.M. (2006). Dividend policy and the earned/contributed capital mix: a test of the lifecycle theory. Journal of Financial Economics, 81, 227-254.

Debnath, P. (2017). Assaying the Impact of Firm's Growth and Performance on Earnings Management: An Empirical Observation of Indian Economy. International Journal of Research in Business Studies and Management, 4(2), 30-40.

Dechow, P. M., Sloan, R. G., \& Sweeney, A. P. (1995). Detecting earnings management. The Accounting Review, 70, $193-225$.

Dechow, P., \& Dichev, I. (2002). The quality of accruals and earnings: The role of accrual estimation errors. The Accounting Review, 77(4), 35-59.

Dechow, P.M., Ge, W., \& Schrand, C. (2010). Understanding earnings quality: A review of the proxies, their determinants and their consequences. Journal of Accounting and Economics, 50(2), 344-401.

DeGeorge, F., Patel, J., \& Zeckhauser, R. (1999). Earnings management to exceed thresholds. The Journal of Business, 72(1), 133.

Demerjian, P.R., Lev, B., Lewis, M.F., \& McVay, S.E. (2013). Managerial ability and earnings quality. The Accounting Review, 88(2), 463-498

Dempster, G., \& Oliver, N. (2019). Financial Market Pricing of Earnings Quality: Evidence from a Multi-Factor Return Model. Open Journal of Business and Management, 7, 312-329. doi: 10.4236/ojbm.2019.71021.

Devin, S.P., Ara, O.F., \& Jafari, M. (2019). The Impact of Loans to Deposit Ratio (LTD) and Return on Assets (ROA) on the Capital Adequacy Ratio of the Tehran Stock Exchange and OTC. Journal of Management and Accounting Studies, 7(1), 2126.

Du, Q., \& Shen, R. (2018). Peer performance and earnings management. Journal of Banking \& Finance, 89, $125-137$.

Easley, D., \& O'Hara, M. (2004). Information and the Cost of Capital. Journal of Finance, 59, 1553-1583. https://doi.org/10.1111/j.1540-6261.2004.00672.x

Ecker, F., Francis, J., Kim, I., Olsson, P., \& Schipper, K. (2006). A Returns-Based Representation of Earnings Quality. The Accounting Review, 81, 749-780. https://doi.org/10.2308/accr.2006.81.4.749

Fama, E.F. (1970). Efficient capital markets: a review of theory and empirical work. Journal of Finance, 25, $383-417$.

Fathi, J. (2013). The Determinants of the Quality of Financial Information Disclosed by French Listed Companies.Mediterranean Journal of Social Sciences, 4(2), 319-336.

Francis, J., LaFond, R., Olsson, P. M., \& Schipper, K. (2004). Costs of equity and earnings attributes. The Accounting Review, 79(4), 967-1010.

Francis, J.R., \& Yu, M.D. (2009). Big 4 office size and audit quality. The Accounting Review, 84(5), 1521-1552. https: //www.jstor.org/stable/27784231

Francis, J., LaFond, R., Olsson, P.M., \& Schipper, K. (2005). The market pricing of accruals quality. Journal of Accounting and Economics, 39(2), 295-327.

Geetha, E., \& Swaaminathan, T.M. (2015). A study on the factors influencing stock price A Comparative study of Automobile and Information Technology Industries stocks in India. International journal of Current Research and Academic Review, 3(3), 97-109.

Gitman, L., \& Zutter, C.J. (2012). Principles of Managerial Finance. Harlow: Pearson.

Gombola, M.J., Ho, A.Y.F., \& Huang, C.C. (2016). The effect of leverage and liquidity on earnings and capital management: Evidence from U.S. com-mercial banks. International Review of Economics \& Finance, 43, 35-58.

Gujarati, D.N. (2004). Basic Econometrics (4th Edition). UAS: McGraw-Hill Companies.

Gul, F.A., Fung, S.Y.K., \& Jaggi, B. (2009). Earnings quality: Some evidence on the role of auditor tenure and auditors' industry expertise. Journal of Accounting and Economics, 47(3), 265-287.

Gunawan, I.K., Darmawan, N.A.S., \& Purnamawati, I.G.A. (2015). The Influence of Company Size, Profitability, and Leverage on Earnings Management at Manufacturing Companies Listed on Indonesia Stock Exchange (IDX). JIMAT, 3(1), 1-18.

Habib, A., Bhuiyan, B.U., \& Islam, A. (2013). Financial distress, earnings management and market pricing of accruals during the global financial crisis. Managerial Finance, 39(2), 155-180.

Healy, P.M., \& Whalen, J.M. (1999). A Review of the Earnings Management Literature and Its Implications for Standard Setting. Accounting Horizons, 13, 365-383. https://doi.org/10.2308/acch.1999.13.4.365

Huang, Q., \& Skantz, T.R. (2008). The Quality of Pro Forma Earnings: An Examination of the Adverse Selection Component of the Bid-Ask Spread Around Earnings Announcements. SSRN Electronic Journal, 1-50. DO.10.2139/ssrn.1266800

Huynh, Q. L. (2018). Earnings Quality with Reputation and Performance. Asian Economic and Financial Review, 8(2), 269-278.

Jafari, H. (2016). Financial reporting quality, Debt maturity investment Efficiency Case Study: Stock Market Listed Chemical and pharmaceutical industries. Bulletin de la Société des Sciences de Liège, 85, 1283 - 1296.

Jaggi, B., Leung, S., \& Gul, F. A. (2009). Family control, board independence and earnings management: Evidence based on Hong Kong firms. Journal of Accounting and Public Policy, 28(4), 281-300.

Jensen, M. C., \& Meckling, W. C. (1976). The theory of the firm: Managerial behaviour, agency costs and ownership structure. Journal of Financial Economics, 3(4), 305-360.

Jeong, S., \& Rho, W.J. (2004). Big Six auditors and audit quality: the Korean evidence. International Journal of Accounting. 39(2), 175-196.

Jiraporn, P., Miller, G. A., Yoon, S. S., \& Kim, Y. S. (2008). Is earnings management opportunistic or beneficial? An agency theory perspective. International Review of Financial Analysis, 17(3), 622-634. 
Jones, T.M. (1991). Ethical decision making by individuals in organizations: An issue-contingent model. The Academy of Management Review, 16(2), 366-395.

Kabajeh, M.A.M., Al Nu'aimat, S.M.A., \& Dahmash, F.N. (2012). The Relationship between the ROA, ROE and ROI Ratios with Jordanian Insurance Public Companies Market Share Prices. International Journal of Humanities and Social Science, 2(11), 115-120.

Kathuo, S. M. (2015). Effect of mobile banking on the financial performance of banking institutions in Kenya. Strategic journal of business \& change management, 2(2), 37-48.

Kazemian, S., \& Sanusi, Z. M. (2015). Earnings management and ownership structure. Procedia Economics and Finance, 31 , 618-624.

Kieso, D. E., Weygandt, J., \& Warfield, T. D. (2012). Intermediate Accounting: IFRS Edition. USA: John Willey and Sons Inc.

Kolb, R. (2006). The Ethics of Executive Compensation. Malden: Blackwell Publishing.

Kothari, S. P., Leone, A. L., \& Wasley, C. E. (2005). Performance matched discretionary accrual measure. Journal of Accounting and Economics, 39(1), 163-197.

Krishnan, G.V. (2003). Audit Quality and the pricing of Discretionary Accruals. Auditing: A Journal of Practice \& Theory, 22(1), 109-126.

Latif, K., Bhatti, A.A., \& Raheman, A. (2017). Earnings quality: A missing link between corporate governance and firm value. Business \& Economic Review, 9(2), 255-280.

Leggett, D. M., Parsons, L. M., \& Reitenga, A. L. (2016). Real Earnings Management and Subsequent Operating Performance. IUP Journal of Operations Management, 15(4), 7-32.

Leland, H., \& Pyle, D. (1977). Information asymmetries, financial structure, and financial intermediation, Journal of Finance, 32, 371-388.

Li, H. (2014). Top executives' ability and earnings quality: Evidence from the Chinese capital markets. International Journal of Financial Research, 5(4), 79-86.

Lipe, R. (1990). The Relation Between Stock Returns and Accounting Earnings Given Alternative Formation. Accounting Review, 65(1), 49-71.

Machdar, N.D., Manurung, A., \& Murwaningsari, E. (2017). The Effects of Earnings Quality, Conservatism, and Real Earnings Management on the Company's Performance and Information Asymmetry as a Moderating Variable. International Journal of Economics and Financial Issues, 7(2), 309-318.

Mboi, C., B., Muturi, W., \& Wanjare, J. (2018), Effect of Short-term Debt to Total Assets Ratio on Financial Performance of Medium-sized and Large Enterprises in Kenya. Research Journal of Finance and Accounting, 9(18), 40-49.

Mcnichols, M.F. (2002). Discussion of the quality of accruals and earnings: The role of accrual estimation errors. Accounting Review, 77, 61-69.

Menon, K., \& Williams, D.D. (2004). Former audit partners and abnormal accruals. The Accounting Review, 79(4), $1095-1118$.

Mitra, R. (2016). The Association between Earnings Quality and Firm-Specific Return Volatility: Evidence from Japan. Review of Accounting and Finance, 15, 294-316. https://doi.org/10.1108/RAF-08-2015-0100

Mostafa, W. (2020). Operating performance and manipulation of accruals. Management Science Letters, $10(5), 985-994$.

Mostafa, W., \& Ibrahim, M. (2019). Firm performance and earnings management. Academy of Accounting and Financial Studies Journal, 23(3), 1-11.

Myers, L. A., \& Skinner, D. J. (2000). Earnings momentum and earnings management. Working paper, University of Michigan.

Nie, F.F. (2006). Corporate governance and the quality of accounting earnings: a Canadian perspective. international Journal of Managerial finance, 2(4), 302-327.

Niskanen, M., Karjalainen, J., \& Niskanen, J. (2011). Demand for audit quality in private firms: evidence on ownership effects. International Journal of Auditing, 15(1), 43-65. https://doi.org/10.1111/j.1099-1123.2010.00422.X

Nuryaman, N. (2013). The influence of earnings management on stock return and the role of audit quality as a moderating variable. International Journal of Trade, Economics and Finance, 4(2), 73-78.

Okolie, A.O. (2014). Accrual - based earnings management, corporate policies and managerial Decisions of Quoted Companies in Nigeria. Research Journal of Finance and Accounting, 5(2), 1-14.

Okolie, A.O., Izedonmi, F.O., \& Enofe, A.O. (2013). Audit quality and accrual - based earnings management of quoted companies in Nigeria. Journal of Economics and Finance, 2(2), 7-16.

Park Y., \& Shin, H. (2004). Board composition and earnings management in Canada. Journal of Corporate Finance, 10, 431457.

Perotti, P., \& Wagenhofer, A. (2014). Earnings Quality Measures and Excess Returns. Journal of Business Finance and Accounting, 41, 545-571. https://doi.org/10.1111/jbfa.12071

Piot, C., \& Janin, R. (2007). External auditors, audit committees and earnings management in France. European Accounting Review, 16(2), 429-454.

Prior, D., Surroca, J., \& Tribo, J. (2007). Earnings management and corporate social responsibility. Working Paper No. 06-23, Business Economics Series 06, September 2007, Universidad Carlos III de Madrid, Madrid, 1-42. Retrieved from: https:/earchivo.uc3m.es/bitstream/handle/10016/428/wb062306.pdf?sequence=1.

Ross, S.A. (1977). The determination of financial structure: The incentive signaling structure. Bell Journal of Economics, 8, 2340. 
Sáenz-González, J.S., \& García-Meca, E. (2014). Does corporate governance influence earnings management in Latin American markets?. Journal of Business Ethics, 121(3), 419- 440.

Saleh, I.H., \& Al-Sraheen, D.A.O. (2017). Does the monitoring mechanisms considered as dilemma against the practices of earnings management. International Business Research, 10(10), 39-44.

Sayari, S., Omri, A., Finet, A., \& Harrathi, H. (2013). The Impact of Earnings Management on Stock Returns: The Case of Tunisian Firms. International Research Journal of Accounting and Auditing, 1(1), 7-21.

Schipper, K. (1989). Commentary on earnings management. Accounting Horizons, 3(4), 91-102.

Shbeilat, M., \& Abdel-Qader, W. (2018). Independence Dilemma and the Reliability of the Audit Report: Qualitative Evidence from Jordan. Australian Academy of Accounting \& Finanace Review, 4(1), 22-36

Shehadeh, H. (2011). Financial analysis and cash management. Business and Management Review, 1(5), 1-9.

Shen, C. H., \& Chih, H. L. (2007). Earnings Management and Corporate Governance in Asia's Emerging Markets. Corporate Governance: An International Review, 15(5), 999-1021.

Spence, M. (1973). Job market signaling. Quarterly Journal of Economics, 87, 355-374.

Subramanyam, K.R. (1996). The pricing of discretionary accruals. Journal of Accounting and Economics, 22, $249-281$.

Sucuahi, W., \& Cambarihan, J. M. (2016). Influence of Profitability to the Firm Value of Diversified Companies in the Philippines. Accounting and Finance Research, 5(2), 149-153.

Sun, J., \& Liu, G. (2011). Client-specific litigation risk and audit quality differentiation. Managerial Auditing Journal, 26(4), 300-316.

Sun, L., \& Rath, S. (2008). Fundamental determinants, opportunistic behavior and signaling mechanism: an integration of earnings management perspectives. International Review of Business Research Papers, 4(4), 406-420.

Sun, N., Salama, A., Hussainey, K., \& Habbash, M. (2010). Corporate environmental disclosure, corporate governance and earnings management. Managerial Auditing Journal, 25(7), 679-700. https://doi.org/10.1108/02686901011061351

Sun, Q., Yung, K., \& Rahman, H. (2012). Earnings quality and corporate cash holding Accounting \& Finance, 52(2), 543-571.

Tabassum, N., Kaleem, A., \& Nazir, M.S. (2014). Real earnings management and future performance. Global Business Review, $16(1), 21-34$.

Tangjitprom, N. (2013). The role of corporate governance in reducing negative effect of earnings management. International Journal of Economics and Finance, 5(3), 213-220.

Warrad, L. (2017). The Influence of Leverage and Profitability on Earnings Quality: Jordanian Case. Behavioral \& Social Sciences Librarian, 7(10), 62-81

Wasiuzzaman, S., Iman, S., \& Nejad, N. (2015). Prospect theory, industry characteristics and earnings management: A study of Malaysian industries. Review of accounting and finance, 14(3), 324-347.

World Bank (2004). Hashemite Kingdom of Jordan: Accounting and Auditing, World Bank: Washington DC. Retrieved from: https://openknowledge.worldbank.org/handle/10986/14552 [accessed on August 17th, 2020]

Wysocki, R.K. (2011). Effective Project Management: Traditional, Agile, Extreme (6th edition). Hoboken, NJ: John Wiley \& Sons.

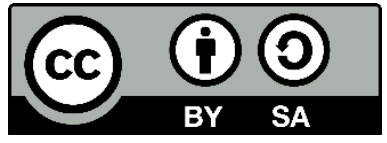

(C) 2020 by the authors. Licensee ACRN Publishing, Austria, Editor in Chief Prof. Dr. Othmar M. Lehner. This article is an open access article distributed under the terms and conditions of the Creative Commons Attribution (CC BY SA) license (https://creativecommons.org/licenses/by-sa/4.0/) 